\title{
Redox alterations of platelets and erythrocytes represent progression marker and pathogenetic determinants in Kawasaki disease
}

\author{
Elisabetta Straface ${ }^{1 *}$, Donatella Pietraforte ${ }^{2}$, Lucrezia Gambardella ${ }^{1}$, Domenico Del Principe ${ }^{1}$, Alessandra Marchesi ${ }^{3}$, \\ Marina Viora', Isabella Tarissi De Jacobis ${ }^{3}$, Alberto Villani ${ }^{3}$, Walter Malorni ${ }^{1}$ \\ From 71st Congress of the Italian Society of Pediatrics. Joint National Meeting SIP, SIMGePeD, Study Group \\ on Pediatric Ultrasound, SUP Study Group on Hypertension \\ Rome, Italy. 4-6 June 2015
}

\section{Background}

Kawasaki disease (KD) is a rare generalized systemic vasculitis of unknown etiology in which the main complication is the development of coronary artery abnormalities. Considering that an inflammation-associated systemic pro-oxidant status could play a critical pathogenetic role in KD progression [1], we evaluated some peripheral blood redox-associated parameters, including redox and aging features associated with red blood cells (RBCs) and platelets (PLT) integrity as possible pathogenetic determinants or progression markers in $\mathrm{KD}$ disease.

\section{Materials and methods}

The $18 \mathrm{KD}$ patients, aged between 6 and 24 mounts, were recruited from the Bambino Gesù Hospital (BGH) of Rome (Italy) and studied, after obtaining the parent informed consent, before to start therapy with intravenous immunoglobulin and aspirin. Ten age-matched healthy donors (HD) were enrolled as controls. The study was approved by the BGH Institutional Review Board.

Morphological, biophysical, biochemical and flow cytometrical methods were used to evaluate: i) reactive oxidizing species (ROS) formation and oxidative stressrelated biomarkers [3-nitrotyrosine, the endothelial nitric oxide synthase inhibitor, asymmetric dymethylarginine (ADMA), the pro-oxidant enzyme myeloperoxidase (MPO)]; ii) PLT integrity and function, including

\footnotetext{
* Correspondence: elisabetta.straface@iss.it

'Department of Therapeutic Research and Medicine Evaluation, Istituto

Superiore di Sanità, Rome, 00161, Italy

Full list of author information is available at the end of the article
}

PLT activation and procoagulant state (annexin V positivity); iii) RBCs homeostasis, including $\mathrm{RBC}$ aging markers (glycophorin A and CD47 expression, annexin V positivity).

\section{Results}

With respect to $\mathrm{HD}$, peripheral blood of KD patients showed increased levels of $\mathrm{O}_{2} \cdot$, $\cdot \mathrm{NO}, 3$-nitrotyrosine and $\mathrm{MPO}$, and decreased ADMA concentration (Figure 1). In RBCs, alterations of biomarkers correlated with cell aging and death (i.e., decreased glycophorin $\mathrm{A}$ and CD47 expression, increased percentage of annexin $\mathrm{V}$ positive cells) [2] occurred. Interestingly, we found that two different PLT sub-populations seem to coexist in the KD peripheral blood (Figure 1): i) annexin $\mathrm{V}$ positive PLT, showing loss of mitochondrial membrane potential (considered as pro-coagulant) and ii) annexin $\mathrm{V}$ negative PLT, showing mitochondrial membrane hyperpolarization (non-pro-coagulant per se). These two sub-populations may considerably affect the coagulation cascade and inflammatory responses in KD patients [3].

\section{Conclusions}

These results lead us to hypothesize that the oxidative/ nitrative stress occurring in KD inflamed blood vessels could alter both RBCs and PLT homeostasis, resulting in a sort of premature aging in these circulating cells that could lead to anemia and the formation of blood clots. These alterations could play a pathogenetic role in the cardiovascular complications often associated with KD but, in addition, the possible use of these data as real time biomarkers of progression cannot be ruled out. 


\section{Acknowledgements}

We thank Rosa Vona for technical assistance.

\section{Authors' details}

'Department of Therapeutic Research and Medicine Evaluation, Istituto Superiore di Sanità, Rome, 00161, Italy. ${ }^{2}$ Department of Cell Biology and Neurosciences, Istituto Superiore di Sanità, Rome, 00161, Italy. ${ }^{3}$ General Pediatric and Infectious Disease Unit, Internal Care Department, Bambino Gesù Children's Hospital, Rome, 00165, Italy.

Published: 30 September 2015

\section{References}

1. Cheung YF, K O, Woo CW, Armstrong S, Siow YL, Chow PC, et al: Oxidative stress in children late after Kawasaki disease: relationship with carotid atherosclerosis and stiffness. BMC Pediatr 2008, 8:20

2. Straface E, Marchesi A, Gambardella L, Metere A, Tarissi de Jacobis I, Viora $\mathrm{M}$, et al: Does oxidative stress play a critical role in cardiovascular complications of Kawasaki disease? Antioxid Redox Signal 2012, 17(10):1441-1446.

3. Pietraforte D, Gambardella L, Marchesi A, Tarissi de Jacobis I, Villani A, Del Principe D, et al: Platelets in Kawasaki patients: two different populations with different mitochondrial functions. Int J Cardiol 2014, 172(2):526-528.

doi:10.1186/1824-7288-41-S2-A69

Cite this article as: Straface et al:: Redox alterations of platelets and erythrocytes represent progression marker and pathogenetic determinants in Kawasaki disease. Italian Journal of Pediatrics 2015 41(Suppl 2):A69.

\section{Submit your next manuscript to BioMed Central and take full advantage of:}

- Convenient online submission

- Thorough peer review

- No space constraints or color figure charges

- Immediate publication on acceptance

- Inclusion in PubMed, CAS, Scopus and Google Scholar

- Research which is freely available for redistribution

Submit your manuscript at www.biomedcentral.com/submit 